\title{
The Effects of Asphodel (Asphodelus aestivus Brot.) Rhizome Extract Administration in the Treatment of Thermally Induced Wound in Rats
}

\author{
Okan Arihan", Omer Akgul², Gokhan Oto ${ }^{3}$, Serkan Yildirim4, Huseyin Eroglus,*, Gulhan Bora ${ }^{2}$ \\ ${ }^{1}$ Department of Physiology, Faculty of Medicine, Hacettepe University, Ankara, TURKEY. \\ ${ }^{2}$ Department of Microbiology, Faculty of Pharmacy, Van Yuzuncu Yil University, Van, TURKEY. \\ ${ }^{3}$ Department of Pharmacology, Faculty of Medicine, Van Yuzuncu Yil University, Van, TURKEY. \\ ${ }^{4}$ Department of Pathology, Veterinary Faculty, Ataturk University, Erzurum, TURKEY. \\ ${ }^{5}$ Department of Biology, Faculty of Science, Van Yuzuncu Yil University, Van, TURKEY.
}

\begin{abstract}
Background: Burn wound is an important health problem worldwide. Serious outcomes related with burn occur and treatments focus on healing of the wounded area with dermal preparations containing chemicals avoiding growth of pathogenic organisms. Plants are important sources for both modern pharmacy to find new molecules used in modern medication as well as in traditional medicinal practices. Many plants are used for treatment of burn wounds. Asphodel (Asphodelus aestivus Brot.) is a naturally found plant in the Mediterranean flora. It is also used in traditional medicinal practices in Turkey. Aim: In this study it was aimed to test wound healing effect of Asphodel. Materials and Methods: An ointment prepared with a $5 \%$ methanolic extract of Asphodel was used. 4 groups were formed as control, wound, wound + asphodel and wound + standard drug (oxytetracyclin hydrochloride) ( $n=8$ in each group). Burn wound was established with a thermal induction. Biochemical, microbiological and histopathological evaluations were performed. Results: Biochemical results (Alt, Ast, Glucose, Ldh) obtained from blood samples showed no adverse effect of this administration. Microbiological results showed a protective effect of Asphodel similar with standard drug. Histopathological evaluation also presented an ameliorating effect as standard drug. Conclusion: Results of this study states that traditional use of this plant for the treatment of burn/wound/ulcer in traditional medicine applications is valid.
\end{abstract}

Key words: Burn, Asphodel, Asphodelus, Rat, Skin, Ethnopharmacology.

\section{INTRODUCTION}

Plants provide both important chemicals for modern chemical therapeutic methods and for traditional folk medicine treatments. According to fossil records humans have been using plants as medicines at least for 60,000 years. ${ }^{1}$ Modern medicine brought effective treatments for diseases which devastated various ancient populations, however, almost more than $80 \%$ of the World's population still depends on traditional medicinal practices for certain skin disorders. ${ }^{2,3}$ Number of plant species used in the world for medical purposes are estimated in a range between 50,000 to 70,000. ${ }^{4}$ Asphodelus aestivus Brot. (Xanthorrhoeaceae) which is a species of Mediterranean element is defined from Portugal and are seen in northwest, east and west parts of Turkey. ${ }^{5}$ Relevant information about the healing effect of wounds with Asphodel (Asphodelus aestivus Brot.) among these species can be found in the records of Ibn-i Sina (Avicenna). There are records for Asphodel for treatment of wounds and eczema in ethnobotanical studies carried out in various regions of Turkey. ${ }^{6}$ Tuzlaci and Aymaz recorded that it is also used against burn and hemorrhoids as well as for wound healing in Balikesir-Gonen, Northwestern-
Submission Date: 26-07-2020; Revision Date: 08-10-2020; Accepted Date: 23-02-2021

DOI: 10.5530/ijper.55.2.87 Correspondence: Dr. Hüseyin Eroğlu Research Assistant, Department of Biology, Faculty of Science, Van Yuzuncu Yil University, Van/ TURKEY.

Phone no: +90 5364847232 Email id: huseyineroglu_41@ hotmail.com

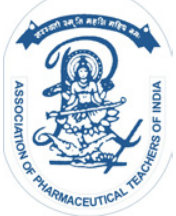

www.ijper.org 
Turkey. ${ }^{7}$ In another study, Asphodel was reported for wound healing around Manisa-Yunt Mountain, Western Turkey. ${ }^{8}$ Asphodel was used against skin diseases in Cyprus and Spain ${ }^{9}$ in a similar manner. However, no scientific study has been carried out in an animal model to test the effect of this species on wound healing. In another study, it has been shown that the Asphodel has an anti-ulcerogenic effect. ${ }^{10}$ When the ethnobotanical data and the anti-ulcerogenic activity are evaluated together, it can be thought that the wound healing of the Asphodel requires scientific investigation. In addition, the antimicrobial effect of another species of Asphodel (Asphodelus tenuifolius) was studied and ethanol, methanol and aqueous extracts were observed to exert similar activity. ${ }^{11}$

For wound healing, in general the skin is shaved in rats or rabbits and a wound is formed as a mechanical wound by means of a biopsy instrument or as a thermal wound with a hot object or setup. ${ }^{12,13}$ In wound treatment, it is aimed to prevent all or part of the damage in the tissue to be ameliorated and to prevent further detoriation of the damaged skin by pathogens. ${ }^{14}$ In addition avoiding bacterial growth is another target of wound healing treatment. Studies on pathogenic micro-organisms causing wound infections have been performed in the World. ${ }^{15}$ Aim of this study is to examine therapeutic effect of Asphodelus aestivus Brot. following a thermal wound in rats.

\section{MATERIALS AND METHODS}

Following approval from Animal Experiments Ethics committee a total of 32 female Wistar albino rats were used. Rats in Van Yuzuncu Yil University Experimental Medicine Research Facility were divided into 4 groups, each consisting of 8 individuals. After shaving of the hair in the dorsal part of rat, wound was formed with heat under anesthesia. For this application, a cylindrical metal with a diameter of $2.5 \mathrm{~cm}$ was placed in the water at $100^{\circ} \mathrm{C}$ for $30 \mathrm{~min}$ and then contacted for $10 \mathrm{sec}$ to the dorsal skin without pressure. ${ }^{12}$ Subcutaneous (SC) $10 \mathrm{ml} / \mathrm{kg}$ of saline was injected to compensate the loss of fluid in the rat after the burn. This SC administration was applied away from injury site.

Asphodel specimen was collected in 2017 from Southern Turkey (C5 Adana): Sarıçam, Çukurova University Campus, surroundings of dam lake, road side, Pinus openings, $37^{\circ} 03^{\prime} 54^{\prime \prime}$ N, $35^{\circ} 21^{\prime} 31^{\prime \prime}$ E, 70 $\mathrm{m}, 08.03 .20016, H$. Eroğlu 1218 and a voucher specimen was formed in Van Yuzuncu Yil University Herbarium (number 164102). Dried underground parts of plant were extracted with methanol in a soxhlet extractor for
$48 \mathrm{~h}$. Methanol at the end of the extraction method was purged by rotary evaporator. Then, concentrated under reduced pressure and finally freeze-dried at $-40^{\circ} \mathrm{C}$. The yield of this process was $16.6 \%$.

Group 1 (Control Group, $n=8$ ): No wound was formed. The tissues were collected and compared with the other groups. Group $2(n=8)$ : No treatment was performed after wound formation. Group 3 (Wound+Asphodel Group, $n=8$ ). After the wound was formed, the ointment prepared with Asphodelus aestivus extract (5\% in an inert wax) was applied topically to the wound area twice a day. Group 4 (Wound+Standard Drug Group, $n$ $=8$ ). After the wound was formed, the standard wound cream (antibiotic ointment containing oxytetracyclin hydrochloride) was applied topically to the wound area twice a day. Preparation of 5\% extract ointment was performed according to our previous preliminary experiences on the subject.

After the wound formation, this administration was continued for 12 days and skin samples were incised from rats under anesthesia for histopathological and biochemical analysis at the end of 12 days. Macroscopic and microscopic findings were compared between the groups. In addition, swab samples were taken from the wound area on the $5^{\text {th }}$ and $10^{\text {th }}$ days for the examination of the antibacterial properties of the ointment prepared with extract and evaluated in the microbiology laboratory. In addition to these assays, blood samples were taken for biochemical analysis.

\section{Histopathological Method}

Skin tissue samples taken for histopathological evaluation of necropsy were fixed in $10 \%$ formalin solution for $48 \mathrm{hr}$. Following routine tissue procedures, they were embedded in paraffin blocks. $4 \mu \mathrm{m}$ thick sections were taken from each block. Preparations for histopathological examination were stained with hematoxylin-eosin (HE) and examined with light microscopy (Leica DM 1000, Germany). Sections were evaluated semi-quantitatively as non-positive (-), mild $(+)$, moderate $(++)$ and severe $(+++)$.

\section{Microbiological Method}

The experimental animals were divided into three groups (2, 3 and 4) for microbiological evaluation. Swab specimens were taken from wound sites twice on $5^{\text {th }}$ and $10^{\text {th }}$ days. The swab sampling was obtained from the area up to the site joining with the intact tissue region of the wound site and directly sown into the Shadler Broth. Shadler Broth was incubated at $37^{\circ} \mathrm{C}$ for $24-48$ $72 \mathrm{hr}$. From tubes in which bacterial growth is observed inoculations were performed into 5\% sheep blood agar, 
McConkey agar, Eosin Methylene Blue agar (EMB) and incubated at $37^{\circ} \mathrm{C}$ for $24-48-72 \mathrm{hr}$. Colony morphology, hemolysis properties, gram staining, catalase test, oxidase test, lactose activity, PYR test (L-pyrrolidonyl$\beta$-naphthylamide hydrolysis activity), coagulate test and color rendering properties in EMB agar were taken into consideration. Identifications were performed in Vitek II device (bio Merieux) following incubation in 5\% sheep blood agar at $37^{\circ} \mathrm{C}$ for $24-48-72 \mathrm{hr}$.

\section{Biochemical Analysis}

Following anesthesia blood samples were obtained from venous blood into special biochemical sampling tubes. Alanine transaminase (ALT), aspartate amino transferase (AST), glucose and lactate dehydrogenase (LDH) were measured with automatic sampling device for biochemical tests. Animals were not fasting during blood sampling.

\section{Statistical Analysis}

In the evaluation of data, Kruskal-Wallis and Mann Whitney $\mathrm{U}$ tests for evaluation of continuous variables and other relevant tests for semi-quantitative results were used. SPSS 20 software program was used for analysis.

\section{RESULTS}

\section{Histopathology results}

When the skin tissues of the rats in Control Group were examined, the epidermis and dermis layers were found to have normal histological structure (Figure 1a). In the skin tissues of rats in Wound Group, there was an intense necrotic mass in the wound area and a mononuclear cell infiltration composed of neutrophils. Epithelial regeneration was started and the presence of a loose collagen was determined. The granulation tissue was found to develop slightly (Figure 1b). Most of the necrotic mass in the skin tissues of Wound+Asphodel Group was cleared. It was determined that granulation tissue and angiogenesis was developed intensely, a tight collagen tissue was developed and epithelial regeneration progressed considerably (Figure 1c).
When compared with wound group, it was determined that epithelial regeneration, angiogenesis, granulation tissue, inflammation and collagenization were significantly increased $(p<0.05)$. The necrotic mass was completely cleared in Wound + standard drug Group. It was determined that a chronic granulation tissue and angiogenesis was developed and a tight collagen structure was formed. Epithelial regeneration was well established (Figure 1d). When compared with the wound group, there was a statistically significant increase in epithelial regeneration, angiogenesis, granulation tissue, inflammation and collagenization in Wound+Asphodel group $(p<0.05)$. Histopathological findings are summarized in Table 1.

\section{Microbiological Findings}

Staphylococcus epidermidis and Escherichia coli were observed in all 3 burn groups. However in lone burn wound group which had no treatment ( $2^{\text {nd }}$ group) Staphylococcus aureus, Enterococcus faecalis and Enterococcus faecium were

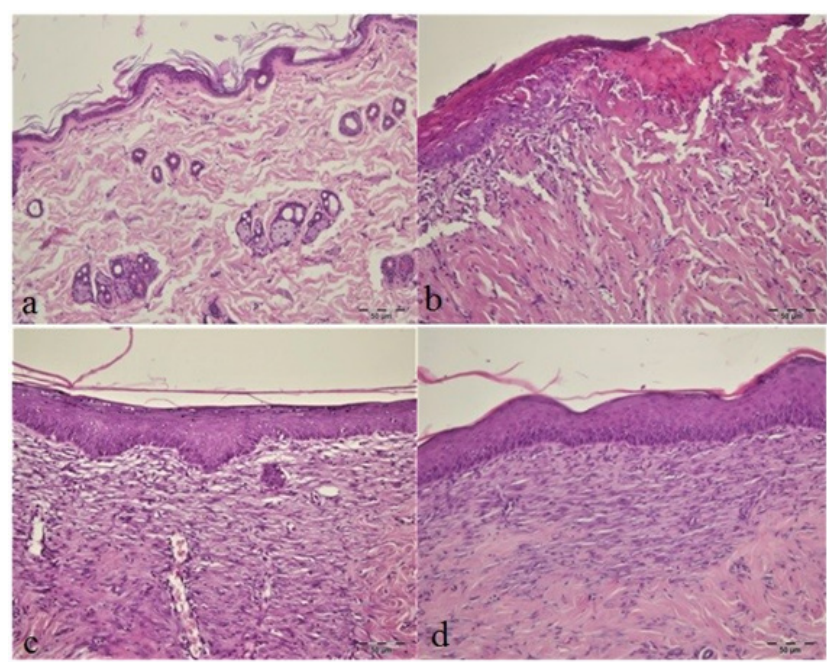

Figure 1: Histopathological findings of four groups. H\&E, Bar: $50 \mu \mathrm{m}$.

a) Control group, Normal histopathological structure. b) Wound group, Necrotic mass, mononuclear cell infiltration, a recent epithelial regeneration, a loose connective tissue in dermis in wound area were observed. c) Wound+Asphodel Group, well developed epithelial regeneration, tight connective tissue in dermis, light mononuclear cell infiltration, strong angiogenesis was observed. d) Wound+standard drug Group, well developed epithelial regeneration, a collagenization that began to mature in the dermis, a slight infiltration of mononuclear cells were observed.

\section{Table 1: Histopathology evaluation table. Sections were evaluated semi-quantitatively as non-positive (-), mild} $(+)$, moderate $(++)$ and severe $(+++)$.

\begin{tabular}{|c|c|c|c|c|}
\hline & Control Group & Wound group & Wound + Asphodel Group & $\begin{array}{c}\text { Wound + Standard drug } \\
\text { Group }\end{array}$ \\
\hline Connective tissue proliferation & - & ++ & +++ & +++ \\
\hline Mononuclear cell infiltration & - & ++ & +++ & ++ \\
\hline $\begin{array}{c}\text { Angiogenesis and } \\
\text { Collagenization }\end{array}$ & - & ++ & +++ & ++ \\
\hline Epithelial proliferation & - & ++ & +++ & ++ \\
\hline
\end{tabular}


Table 2: Results of isolated and identified bacteria from wound samples. Results of isolated and identified bacteria species from wound samples are listed according to each individual rat. A.N. (Animal Number in each group).

\begin{tabular}{|c|c|c|c|c|c|c|}
\hline \multirow[b]{2}{*}{ A. $\mathbf{N}$. } & \multicolumn{2}{|c|}{ Wound Group } & \multicolumn{2}{|c|}{ Wound + Asphodel Group } & \multicolumn{2}{|c|}{ Wound + standard Drug Group } \\
\hline & $5^{\text {th }}$ day & $10^{\text {th }}$ day & $5^{\text {th }}$ day & $10^{\text {th }}$ day & $5^{\text {th }}$ day & $10^{\text {th }}$ day \\
\hline 1 & S. epidermidis & E.coli & E. coli & S. epidermidis & $\begin{array}{l}\text { E.coli + } \\
\text { S. epidermidis }\end{array}$ & S. epidermidis \\
\hline 2 & S. epidermidis & E. coli & E. coli & S. epidermidis & E. coli & S. epidermidis \\
\hline 3 & S. epidermidis & E. coli & E. coli & S. epidermidis & $\begin{array}{l}\text { E. coli + } \\
\text { S. epidermidis }\end{array}$ & S. epidermidis \\
\hline 4 & S. aureus & S. aureus & $\begin{array}{l}\text { E. coli + } \\
\text { S. epidermidis }\end{array}$ & E. coli & E. coli & S. epidermidis \\
\hline 5 & E. faecalis & E. coli & $\begin{array}{c}\text { E. coli }+ \\
\text { S. epidermidis }\end{array}$ & E. coli & S. epidermidis & S. epidermidis \\
\hline 6 & E. coli & E. coli & E. coli & S. epidermidis & E. coli & E. coli \\
\hline 7 & E. faecium & E. coli & E. coli & E. coli & E. coli & S. epidermidis \\
\hline 8 & E. coli & E. coli & - & - & - & \\
\hline
\end{tabular}

Table 3: Biochemical results of groups. ALT: Alanine aminotransferase U/L, AST: Aspartate aminotransferase U/L, GLU: Glucose $\mathbf{m g} / \mathbf{d L}$, LDH: Lactate dehydrogenase U/L. No statistically significant difference was found between groups in listed parameters. $p>0.05$.

\begin{tabular}{|c|c|c|c|c|}
\hline & ALT & AST & GLU & LDH \\
\hline Control & 37.2 & 87.3 & 158.8 & 571.8 \\
\hline Wound & 30.8 & 77.4 & 143.4 & 555.2 \\
\hline Wound + Asphodel & 37.5 & 93.3 & 166.3 & 897.8 \\
\hline Wound + Standard drug & 47.2 & 104.8 & 172.3 & 877.0 \\
\hline
\end{tabular}

also observed in addition to Staphylococcus epidermidis and Escherichia coli. The results of the bacteria isolated from the wound area are given in Table 2.

\section{Biochemical Results}

There was no significant difference between the groups in terms of biochemical results. Although statistically insignificant, highest ALT and AST results were obtained in standard drug group. With the administration of Wound + Asphodel or Wound + Standard drug Glucose and LDH levels rise compared to control and wound groups $(p>0.05)$ (Table 3$)$.

\section{DISCUSSION}

This study was aimed to evaluate wound healing property of Asphodel which is used in traditional medicinal practices for burn wounds.

Histopathological evaluation shows that the thermally generated model has been successfully applied.
Decrease in necrotic mass, enhancement of granulation tissue and angiogenesis in plant extract and standard drug treated groups showed that the improvement in both groups was significantly increased compared to the untreated burn group. This finding shows that its ethnopharmacological use is relevant. Ethnopharmacological use of $A$. aestivus, $A$. luteus, $A$. microcarpus and $A$. tenuifolius in skin disorders is in parallel with our histopathological findings. ${ }^{16,17}$ Although rat skin shows some certain differences in skin structure such as its loose skin and difference in Vitamin C metabolism which is important for collagen formation, it is still a widely used model for wound healing. ${ }^{18}$ Therefore our results should be evaluated as an animal model and not as direct testing of ethnopharmacological knowledge. In similar studies focusing on burn wound healing, ethnopharmacological applications guides researchers to test their effectiveness in modern scientific methodology.

Microbiological results of our study show that number of bacteria present on wound was attenuated with administration of standard drug as well as Asphodel ointment. This situation states a possible antimicrobial activity of Asphodel in this burn model. Microbiological evaluation following a burn was investigated by researchers in both experimental models as well as in field studies. In a study conducted by Bayram Y et al. ${ }^{19}$ between 2009 and 2011 on 179 patients, 250 bacteria were isolated from the wound swab samples. In burn units over a 6-month period in Iran P. aeruginosa (72.7\%), S. aureus (14.4\%) and Staphylococcus epidermidis (7.8\%) were isolated from 82 biopsy specimens obtained from 82 
patients who were hospitalized. ${ }^{15}$ In a study by Agnihotri $\mathrm{N}$ et al. between 1997 and 2002, they isolated 665 bacteria from burn wounds. The most isolated bacteria were $P$. aeruginosa (392) and $S$. aureus (119). ${ }^{20}$ In a study in India, 336 burn wound specimens were evaluated. $54.16 \%$ P. aeruginosa, 20.83\% S. aureus, 3.57\% Klebsiella spp. and $2.67 \%$ E. coli isolation were performed. In our study, burn wounds were formed by a thermal induction in an animal model. 44 swab samples from the wounds were taken from the experimental animals $\left(2^{\text {nd }}, 3^{\text {rd }}\right.$ and $4^{\text {th }}$ group) on the $5^{\text {th }}$ and $10^{\text {th }}$ days. Single isolation from 40 samples and mix isolation from 4 samples were conducted. 26 isolates were E. coli, 18 isolates were $S$. epidermidis, 2 isolates were $S$. aureus and 2 isolates were Enterococcus spp. The presence of different pathogenic bacteria in those listed studies was determined as a result of isolation in burn wounds. The differences in bacteria isolated from burn wounds in humans and animals are thought to vary depending on the flora of the experimental animal facility environment and their body flora. Nevertheless, absence of Staphylococcus aureus, Enterococcus faecalis and Enterococcus faecium in Asphodel as well as standard drug which was present in lone burn group suggests a protective activity of Asphodel. A study by Salhi $e t$ al. ${ }^{21}$ shows an antifungal activity of Asphodelus tenuifolius. Although we did not test antifungal activity in this study, literature on Asphodelus tenuifolius may support our observed antimicrobial activity. Although burn wounds are not infected at the beginning bacterial growth delays the healing and posing a threat for the patient. Thus antibacterial property is an important counterpart of burn therapy with certain ointments. This property is valued in relevant research studies concerning substances of natural origin used for this purpose. ${ }^{22}$ Current study with the prepared $5 \%$ ointment of methanolic extract of Asphodelus aestivus plant shows possible protective nature of this plant species in treatment of burn wounds. Arylcoumarins from Asphodelus microcarpus was shown to exert antimicrobial activity in in-vitro conditions. ${ }^{23}$ Another study on Asphodelus microcarpus also shows antimicrobial activity and also a potential anti-viral activity. ${ }^{24}$ Future studies on Asphodelus aestivus may present active substituents which are responsible from our observed antibacterial activity. Results of biochemical findings state that administration of asphodel or standard drug did not cause a significant alteration in evaluated biochemical parameters. Although there were differences in AST and LDH values between plant and standard drug groups with control in biochemical parameters, no statistically significant difference was observed in these differences. Differences can be detected if they will be repeated with a higher number of samples. Present results state no apparent toxic impact of dermal administration of plant extract on liver. There are reports presenting certain toxicities due to consumption of Asphodelus plant. Two studies by Birincioglu et al. ${ }^{25,26}$ report neurological symptoms, pigmentation in various organs of the body including liver due to Asphodelus aestivus ingestion. However no toxicity was visible on liver in our study according to biochemical results. This situation may be due to route of administration (dermal) compared to oral ingestion in aforementioned studies.

The present findings suggest that traditional use of this plant for the treatment of burn/wound/ulcer in traditional medicine applications is valid to some extent. Similar ointment preparation techniques used in literature ${ }^{27}$ also shows that ethnopharmacological information on wound healing with plant based treatments may reveal some scientifically sound results. In further studies, the investigation of the molecules responsible for the effect in this plant has the potential to present new molecules in this area.

\section{ACKNOWLEDGEMENT}

Authors would like to thank to Sevgi Yuksek for her contribution during experimental procedures. This study was supported by Van Yuzuncu Yil University Scientific Research Coordination Unit with the project number THD-2017-6292.

\section{CONFLICT OF INTEREST}

The authors declare no conflict of interest.

\section{ABBREVIATIONS}

Alt: Alanine transaminase; Ast: Aspartate transaminase; Ldh: Lactate dehydrogenase; SC: Subcutaneous; A.N: Animal number.

\section{REFERENCES}

1. Solecki R. Shanidar IV. a Neanderthal flower burial in northern Iraq. Science. 1975;190(4217):880-1.

2. Steenkamp V, Mathivha E, Gouws MC, Rensburg VCEJ. Studies on antibacterial, antioxidant and fibroblast growth stimulation of wound healing remedies from South Africa. J Ethnopharmacol. 2004;95(2-3):353-7.

3. Priya KS, Gnanamani A, Radhakrishnan N, Babu M. Healing potential of Datura alba on burn wounds in albino rats. J Ethnopharmacol. 2002;83(3):193-9.

4. Leaman DJ. Sustainable wild collection of medicinal and aromatic plants, development of an international standard. Medicinal and Aromatic PlantsSpringer, Netherlands. 2006.

5. Matthews VA. Asphodelus L. Flora of Turkey and the East Aegean Islands, Edinburgh: Edinburgh University Press. 1984;(vol 8):85-6. 
6. Tümen G, Malyer H, Başer KHC, Özaydın S. Plants used in Anatolia for wound healing. Proceedings of the IVth International Congress of Ethnobotany (ICEB 2005). 2005;217:221.

7. Tuzlaci E, Eryasar AP. Turkish folk medicinal plants, Part IV: Gonen-Balıkesir. Fitoterapia. 2001;72(4):323-43.

8. Ugurlu E, Secmen Ö. Medicinal plants popularly used in the villages of Yunt Mountain (Manisa-Turkey). Fitoterapia. 2008;79(2):126-31.

9. González-Tejero MR, Casares-Porcel M, Sánchez-Rojas CP, RamiroGutiérrez JM, Molero-Mesa J, Pieroni A, et al. Medicinal plants in the Mediterranean area: Synthesis of the results of the project Rubia. J Ethnopharmacol. 2008;116(2):341-57.

10. Gurbuz I, Üstün O, Yeşilada E, Sezik E, Akyürek N. In vivo gastro protective effects of five Turkish folk remedies against ethanol-induced lesions. J Ethnopharmacol. 2002;83(3):241-4.

11. Dangi AS, Sharma MR, Yadav JP. Antimicrobial potential of Asphodelus tenuifolius (CAV). J Evol Med Dent Sci. 2013;2(30):5663-7.

12. Gurel A, Armutcu F, Hosnuter M, Unalacak M, Kargi E, Altınyazar C. Caffeic acid phenethyl ester improves oxidative organ damage in rat model of thermal trauma. Physiol Res. 2004;53(6):675-82.

13. Zhu $\mathrm{H}$, Wei $X$, Bian $\mathrm{K}$. Effects of nitric oxide on skin burn wound healing. J Burn Care Res. 2008;29(5):804-14.

14. Irvin TT. Wound healing. Arch Emerg Med. 1985;2(1):3-10.

15. Mamani M, Derakhshanfar A, Niayesh A, Hashemi SH, Yousefi MR, Zavar S. Frequency of bacterial burn wounds infection and antimicrobial resistance in burn center of Bessat Hospital of Hamedan. Iran J Surg. 2009;17(1):1.

16. Irmak F, Kurt YS, Şirvan SS, Serin M, Özağarı A, Karasoy YA. Beneficial effects of Salvia miltiorrhiza in the healing of burn wounds: An experimental study in rats. J Plas Surg Hand Surg. 2018;52(4):229-33.

17. Malmir M, Serrano R, Caniça M, Silva-Lima B, Silva O. A comprehensive review on the medicinal plants from the genus Asphodelus. Plants. 2018;7(1):E20. doi: 10.3390/plants7010020.
18. Abdullahi A, Amini-Nik S, Jeschke MG. Animal Models in Burn Research. Cell Mol Life Sci. 2014;71(17):3241-55.

19. Bayram Y, Parlak M, Aypak C, Bayram I. Three-year review of bacteriological profile and antibiogram of burn wound isolates in Van, Turkey. Int J Med Sci. 2013;10(1):19-23

20. Agnihotri N, Gupta V, Joshi RM. Aerobic bacterial isolates from burn wound infections and their antibiograms a five-year study. Burns. 2004;30(3):241-3.

21. Salhi S, Saghir M, Ayesh S, Terzi V, Brahmi I, Ghedairi N, et al. Antifungal activity of aqueous extracts of some dominant Algerian medicinal plants. Bio Med Res Int. 2017. Article ID 7526291, 6 pages https://doi. org/10.1155/2017/7526291.

22. Hai Z, Ren $Y$, Hu J, Wang H, Qin Q, Chen T. Evaluation of the treatment effect of Aloe vera fermentation in burn injury healing using a rat model. Mediators of Inflammation. 2019;9. Article ID 2020858, https://doi. org/10.1155/2019/2020858.

23. El-Seedi HR. Antimicrobial arylcoumarins from Asphodelus microcarpus. J Nat Prod. 2007;70(1):118-20.

24. DiPetrillo A, Fais A, Pintus F, Santos-Buelga C, González-Paramás AM, Piras $\mathrm{V}$, et al. Broad-range potential of Asphodelus microcarpus leaves extract for drug development. BMC Microbiology. 2017;17(1):159.

25. Birincioglu SS, Calis I, Avci H, Erdag B. Pathological and phytochemical investigation of neuronal lipofuscinosis caused by Asphodelus aestivus in sheep: I. Pathological Findings. Turk J Vet Anim Sci. 2005;29(6):1351-6.

26. Birincioglu SS, Schmahl W, Avci H. Neuronal and extra neuronal lipofuscinosis in merino sheep grazing Asphodelus aestivus seeds in western Turkey. Turk J Vet Anim Sci. 2012;36(5):476-82.

27. Lodhi S, Pawar RS, Jain AP, Singhai AK. Wound healing potential of Tephrosia purpurea (Linn.) Pers. in rats. J Ethnopharm 2006;108(2):204-10.

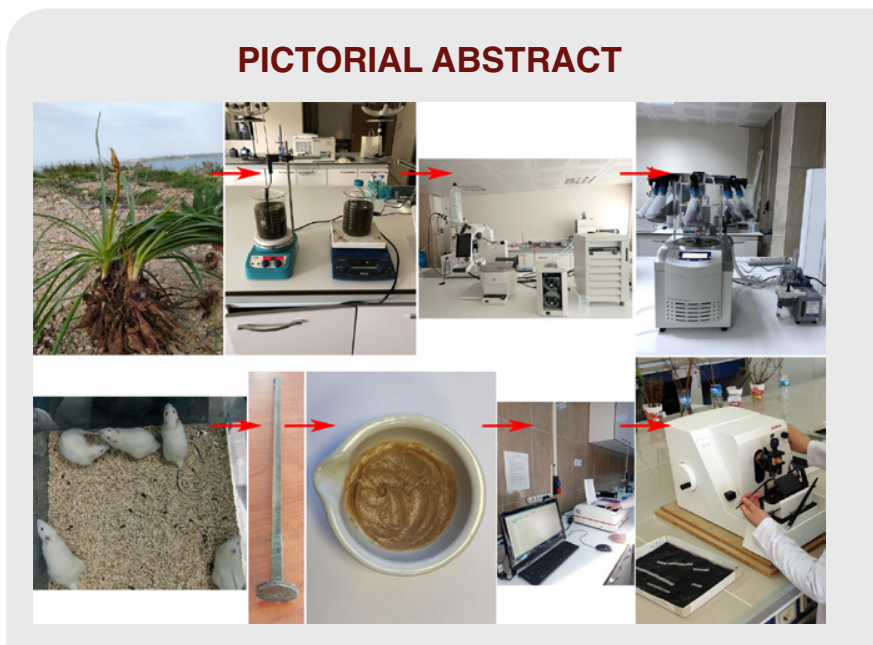

\section{SUMMARY}

- Asphodelus species are used in traditional medicinal practices for wound healing

- Asphodelus aestivus plant was collected and a methanolic extract was prepared. Methanol was evaporated.

- A thermal wound was formed on the back of the rats with a metal rod.

- An ointment containing $5 \%$ of the extract was administered for 12 days on the back of rats.

- $\quad$ Results show an ameliorative activity of Asphodelus in microbiological and histopathological aspects without negatively altering liver parameters in blood such as ALT and AST in this animal model.

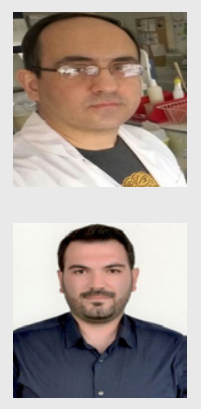

Okan Arihan, Working at Hacettepe University, Faculty of Medicine, Department of Physiology at Ankara, Turkey. Physiology, nutrition, behavior, testing of traditional medicinal practices are areas of expertise. Have more than 50 articles published in different journals.

Omer Akgul, Working as an Assistant Professor at Department of Pharmaceutical Microbiology, Faculty of Pharmacy, Van Yüzüncü Yıl University, TURKEY. Making analysis of phenotypic and genotypic profiles of antibiotic resistance of bacteria that cause human and animal diseases. In addition, conducting epidemiological evaluations of the effects of bacterial infections on human and animal health. Studying the immunological reflections of micro-organisms in infections and the effectiveness of their roles in diagnosis. Evaluating the effects on human health of microbiological contamination in cosmetic products. 
Gokhan Oto, Working at Van Yuzuncu YIl University, Faculty of Medicine, Department of Pharmacology at Van, Turkey. Pharmacology, toxicology, nutrition, behavior, cancer and testing of traditional medicinal practices are areas of expertise. Have more than 80 articles published in different journals on these subjects.

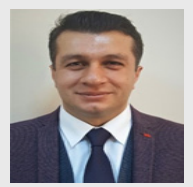

Serkan Yildirim, Working at Erzurum Ataturk University, Faculty of Veterinary, Department of Pathology at Erzurum, Turkey. Pathology, immunohistochemistry, testing of traditional medicinal practices are areas of expertise. Have various articles published in different journals on those subjects.

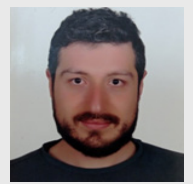

Hüseyin Eroglu, Research Assistant Ph.D in Van Yüzüncü Yıl University in Van-Turkey. Works on plant systematics, molecular phylogeny, palynology, ethnobotany, antioxidant properties. Have more than 20 articles published in different journals on these subjects.

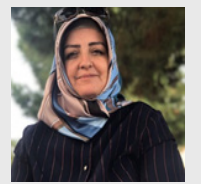

Gulhan Bora, Born in city of Van, which is located in the region of eastern Anatolia, Turkey. Working as an Associate Professor at Van Yuzuncu Yil University, Faculty of Pharmacy, Department of the Pharmaceutical Microbiology. The fields of medical microbiology and clinical microbiology are areas of expertise. Have 30 articles published in various journals. Additionally, educating postgraduate students, and also have both completed and ongoing master of science theses.

Cite this article: Arihan O, Akgul O, Oto G, Yildirim S, Eroglu H, Bora G. The Effects of Asphodel (Asphodelus aestivus Brot.) Rhizome Extract Administration in the Treatment of Thermally Induced Wound in Rats. Indian $\mathrm{J}$ of Pharmaceutical Education and Research. 2021;55(2):491-7. 